\title{
Culture and Labour Productivity: An Empirical Investigation
}

\author{
Dimitrios Bakas $^{a, c}$, Pantelis Kostis ${ }^{b}$, Panagiotis Petrakis ${ }^{b}$ \\ ${ }^{a}$ Nottingham Business School, Nottingham Trent University, UK \\ ${ }^{b}$ Department of Economics, National and Kapodistrian University of Athens, Greece \\ ${ }^{c}$ Rimini Centre for Economic Analysis (RCEA), Canada
}

\begin{abstract}
Culture is considered as one of the most powerful forces that shape human behaviour and thereby economic activity. This paper investigates the effects of culture on labour productivity and examines the cultural traits driving this relationship. Using panel data analysis, empirical evidence is provided covering a sample of 34 OECD countries over a wide period of three decades. Our empirical results suggest a significant positive relationship between the cultural background and labour productivity. The main channels of this positive impact are control and work ethic environment, while obedience has a negative impact on productivity. These findings are robust to a series of robustness checks, including alternative cultural measures, additional control variables, various country samples, and alternative specifications.
\end{abstract}

Keywords: Labour Productivity, Culture, Social Capital, Panel Data

JEL Classification: C23, E24, J24, O40, Z10

\footnotetext{
* We would like to thank three anonymous referees for their constructive comments and helpful suggestions. Any remaining errors are the responsibility of the authors. The authors declare that they have no conflict of interest.

Corresponding author: Dimitrios Bakas, Department of Economics, Nottingham Business School, Nottingham Trent University, 50 Shakespeare Street, Nottingham, NG1 4FQ, United Kingdom. E-mail addresses: dimitrios.bakas@ntu.ac.uk (D. Bakas), pkostis@econ.uoa.gr (P. Kostis), ppetrak@econ.uoa.gr (P. Petrakis).
} 


\section{INTRODUCTION}

Productivity is one of the most important determinants of economic growth; it is the main explanation of why middle-income countries fail to evolve into advanced economies, since these economies face sharp slowdowns in productivity (Agénor et al., 2015). Almost in 85\% of the cases where the rate of output growth has slowed down in an economy can be explained by the slump of Total Factor Productivity (TFP) growth and not by a decline in capital accumulation growth (Eichengreen et al., 2012).

Many low-income countries are characterized by significant low levels of productivity (Petrakis, 2014). Hence, the prospect for improvement for these economies is high, providing them with the opportunity to boost their productivity to higher levels. After a low-income economy is transformed into a middle-income country, it will face various new challenges. Improvement of institutional efficiency will help in reducing uncertainty, freeing resources for the production process and providing incentives for entrepreneurial activity. However, the role of cultural background is extremely important as well. Several authors have distinguished the influence of the cultural background of a society on its economic outcomes from that of institutions (Guiso et al., 2006; Tabellini, 2008; 2010 among others). Culture, thus, continues to play a direct role even for those economies that are characterized by sophisticated formal institutions (Guiso et al., 2015).

The connection between culture and economic outcomes is not a new question (Acemoglu, 2009; Economides and Egger, 2009; De Jong, 2011). Montesquieu (1989 [1748]), Machiavelli (1987 [1519]) and Marshall (1997 [1890]) made references to the general circumstances of the environment that can have an impact on attitude and human conventions (Petrakis and Kostis, 2013). Weber (1958 [1904]) and Harrison and Huntington (2000) stressed the role of religion, while Putnam (1993) broadened the meaning of cultural factors and trust as he relates them to the concept of social capital. Gasper (1996) points out that works on culture and development valuably stress the importance of cultural differences within societies, while, more recently, Guiso et al. (2015) show that culture plays a significant role in explaining persistent differences in the economic success or failure of nations. Moreover, culture is found to determine the levels of self-employment (Marcén, 2014), the size of government (Pham et al., 2018), and also to influence SME profitability (Gaganis et al., 2019), stock markets (Zhou et al., 2019) as well as the market share of foreign 
banks (Xue and Cheng, 2013). Thus, economic literature provides clear evidence that culture can be seen as a powerful force shaping human economic behaviour (Throsby, 2001).

The relationship between culture and productivity, at a national level, has not been explored widely in the literature, although there are some relevant contributions - mainly in the micro-level (Leibenstein, 1982; Kreps, 1990; Goncalo and Staw, 2006). The literature on the effects of culture at the microeconomic level, lies on organizational culture and labour productivity within firms. There is a general consensus that organizational culture has a significant influence on productivity (Mathew, 2007), while other works contend that culture does not determine productivity - actions do (Martinez et al., 2015). Kreps (1990) and Siehl and Martin (1990) provide explicit connection of productivity with organizational culture. Leibenstein (1982) suggests that productivity within a firm might be determined by the 'effort convention' that the firm and its workers adopt, in terms of the firm's or the workers' behaviours. In addition, there are organizations recorded that have adopted collectivist values in order to promote productivity (Goncalo and Staw, 2006). Furthermore, Fenton-O'Creevy (1998) and Ciavarella (2003) argue that there is a connection between workers' behaviour (that is determined by the workers' cultural background) in an organization and their productivity level. Higher involvement in the organization, leads to attachment with the organization and higher motivation and consequently to higher levels of productivity. Many authors record a contagious character to worker productivity (Falk and Ichino, 2006; Mas and Moretti, 2009; Bandiera et al., 2010; De Grip and Sauermann, 2012). Specifically, there is a significant effect between peers; when the workers of a unit are productive a new worker getting in the unit will become also productive. Additionally, there are many studies that associate productivity with organizational climate, since the concepts of climate and culture are often argued to be used interchangeably, although organizational culture is argued to represent the deeper and more fundamental aspects of organizational life (Denison, 1996). For instance, Kopelman et al. (1990) argue that organizations that are characterized by an environment with special emphasis on rewards, will have enhanced clarity in outcome expectations, and therefore to enhanced productivity. Also, Patterson et al. (2004) suggest that concern for employee welfare would lead to satisfaction and thus to increased productivity.

In addition, several studies exist that examine the relationship between specific cultural values and productivity (see Putnam, 1993; Fukuyama, 1995; Erez and Somech, 1996; Cox et 
al., 2011; Bjornskov and Meon, 2015; Fang et al., 2016; Ramos and Paiva, 2017). ${ }^{1}$ More precisely, Cox et al. (2011) found that individualism is positively correlated with productivity while power distance is negatively correlated. Erez and Somech (1996) argue that familiarity and communication between group members, setting stretch goals and performance-based incentive schemes may be identified as factors that would minimize group productivity loss. Fang et al. (2016) state that long term orientation is a significant predictor of student achievement, creativity, and productivity. Ramos and Paiva (2017), more recently, point that honesty in duty displays dedication and dedication increases productivity. Furthermore, an alternative explanation on the connection between culture and productivity is through the effects of trust levels in a society, since trust can be regarded as a cultural value of societies (Putnam, 1993; Stivers, 1994; Fukuyama, 1995). Several articles in the literature explore the connection of trust with productivity (Knack and Keefer 1997, Bjornskov and Meon 2015). Higher levels of trust lead to riskier (Bjornskov and Meon, 2015), and larger (Dearmon and Grier, 2009) investments, leading in turn to higher levels of productivity. In addition, La Porta et al. (1997) point out that social trust allows for the realization of shorter contracts, leading to productivity gains. Kaasa (2016), on the other side, shows that institutional trust and civic participation, and not general trust, are the most significant factors for productivity at the regional level for Europe.

The scope of this paper is to examine the impact of culture on labour productivity and to identify the main channels driving this relationship at the macro-level. To do so, we use a panel research design, for the first time in the literature, and employ data over a long period of three decades (80's, 90's and 00's), providing empirical evidence based on the analysis of a sample of 34 OECD countries. In this way, we first explore the impact of cultural change on labour productivity, using a broader definition of the cultural background, and second, examine the cultural traits driving this relationship.

We contribute to the literature by taking into account various challenges. Several authors show that cultural background of a society is expected to change slowly (Johnston, 1996; De Jong, 2009; Schwartz, 2009; Alesina et al., 2013; Petrakis and Kostis, 2013), however there is still a significant variation over time and across countries (Paldam, 2007; Roth, 2009; De Jong, 2011). To account for this changing behaviour of culture we exploit the panel

\footnotetext{
${ }^{1}$ Most of these empirical works study the effects of culture on productivity, using a cross-section research design and considering the cultural traits as being virtually stable over time. This is the reason why these studies employ a static conception of cultural background, e.g. using the Hofstede's $(1980,2010)$ cultural dimensions, the GLOBE study (House et al., 2004), or questionnaires for specific case studies.
} 
dimension of the data and use a period of three decades for a sample of OECD member countries. Thus, the principal contribution of our study is to present an analysis of a prolonged period of data on cultural background and labour productivity over the last three decades, extending the previous restrictive cross-section analyses into a richer panel data context. ${ }^{2}$ Furthermore, the measurement of culture is found to be rather difficult and prone to measurement error. In this paper, a broader measure of culture is used (Tabellini, 2010; Bützer et al., 2013; Kyriacou and López, 2015), which differentiates this work from other studies in the literature that use some distinct aspects of culture to examine their impact on productivity, like organizational culture (Siehl and Martin, 1990), collectivism (Erez and Somech, 1996; Goncalo and Staw, 2006), organizational climate (Denison, 1996) and trust (Knack and Keefer, 1997; Bjornskov and Meon, 2015). Adding to this, we also investigate the potential channels of the impact of culture that have been proposed in the literature (Knack and Keefer, 1997; Guiso et al., 2006; Tabellini, 2010; Bützer et al., 2013). Moreover, this paper differs from previous works since we investigate the cultural effects on labour productivity, and not on a more general concept of productivity, as labour productivity is found to be the most widely used measure of productivity in the literature (Knack and Keefer, 1997; Hall and Jones, 1999).

Our results show strong evidence of a positive effect of culture on labour productivity. The main channels of this positive association are the control and work ethic environment while obedience seems to have a negative impact on productivity. Our findings are robust to a series of robustness checks, including alternative cultural aspects, additional control variables, various country samples, and alternative specifications.

The structure of the paper is as follows. Section 2 describes the estimation strategy and the data used in the analysis, while Section 3 presents the empirical results and provides robustness checks. Finally, Section 4 concludes.

\footnotetext{
${ }^{2}$ Roth (2009), for example, shows the advantages of the use of a panel research design instead of a cross-section research design for the empirical analysis of the relationship between trust and economic performance, while, De Jong (2011) suggests that a more systematic approach, to overcome the limitations of a cross-section approach, is needed to investigate the relationship for various countries over a long period.
} 


\section{ESTIMATION STRATEGY AND DATA DESCRIPTION}

In order to explore the relationship between culture and labour productivity at the macrolevel, we use an unbalanced panel of decade-level data for OECD countries over a period of three decades (80's, 90's and 00's). The choice of the final sample of countries as well as the time period under investigation is determined by the availability of the data on labour productivity and the cultural variables. We ended up with an unbalanced panel of 34 OECD countries over 3 decades of data for the empirical analysis. ${ }^{3}$

To examine the effects of culture on labour productivity we estimate variations of the following empirical specification:

$$
\operatorname{lpr}_{i t}=a_{i}+\beta \text { culture }_{i t}+\gamma Z_{i t}+\lambda_{t}+u_{i t}
$$

where $i$ denotes the OECD country (with $N_{\max }=34$ ) and $t$ the decade (with $T_{\max }=3$ ). The dependent variable $l p r$ is a measure for labour productivity, culture is a measure of the cultural background, $Z$ is a vector of macroeconomic and institutional control variables, $\alpha_{i}$ is a set of country-specific fixed effects capturing the influence of unobserved country-specific time-invariant heterogeneity, and finally, $\lambda_{t}$ is a set of time dummies, for each decade in the sample, which control for decade-specific effects that are common to all countries. ${ }^{4}$

The analysis of Equation (1) is based on standard panel data estimation methods. We employ the fixed effects (FE) estimation approach which allows for individual heterogeneity using different intercepts across countries and can be estimated using the ordinary least square method. In addition, we include decade time dummies to our estimation to incorporate time specific effects that are common to all countries in the sample. In all estimations, we employ a cluster-robust approach for standard errors to control for possible serial correlation and heteroskedasticity.

The data were drawn from a variety of sources. The cultural variables were obtained from Bützer et al. (2013). Specifically, the series are constructed based on survey data from the

\footnotetext{
${ }^{3}$ The 34 OECD countries in our sample are: Australia, Austria, Belgium, Canada, Chile, Czech Republic, Denmark, Estonia, Finland, France, Germany, Greece, Hungary, Iceland, Ireland, Israel, Italy, Japan, Korea, Luxembourg, Mexico, Netherlands, New Zealand, Norway, Poland, Portugal, Slovak Republic, Slovenia, Spain, Sweden, Switzerland, Turkey, United Kingdom, United States.

${ }^{4}$ The $\beta$ coefficient of the culture measure indicates the average effect of a one-standard deviation change in culture (equivalent to 1.38 on a scale from -3.58 to 3.41 ) on labour productivity growth (equivalent to 1.31 on a scale from -0.01 to 7.61 ).
} 
World Values Survey (WVS) and the European Values Study (EVS). These data are aggregated to decade-level data at a national level, and therefore ended up with one observation over three decades for each country (80's, 90's and 00's, respectively). To measure culture, we use the 'overall civic culture' measure that is created as the first principal component of the alternative traits of a society's civic culture (culture) and captures a broader conception of the social norms, beliefs and values in a society (Tabellini, 2008; 2010). ${ }^{5} \mathrm{We}$ investigate also alternative channels of culture that have been proposed in the literature (see Knack and Keefer, 1997; Guiso et al., 2006; Tabellini, 2010; Bützer et al., 2013; among others), using a set of six distinct cultural variables covering the various dimensions of a society's civic culture such as interpersonal trust (trust), control (control), work ethic (work), obedience (obedience), competition affinity (competition) and honesty (honesty).

Following Bützer et al. (2013), the alternative traits of culture that are used in our analysis are: 1) trust, that is defined as interpersonal trust and is the percentage of respondents in each country who respond that they can trust most people to the question: "Generally speaking, would you say that most people can be trusted or that you can't be too careful in dealing with people?", 2) control, that arises as respondents' answers to the question: "how much freedom of choice and control you feel you have over the way your life turns out?". Life control measures virtually the belief in individual self-determination and refers to people's belief that their lives are controlled by themselves rather than by external factors, and the individual efforts made are likely to be rewarded. 3) The cultural dimension of work emerges as the first component of a PCA including: (a) those who respond 'hard work' to the question of what quality they consider particularly important to teach their children; and (b) the percentage of respondents they say that how they work is very important for their lives. 4) The cultural dimension of obedience arises as the first principal component of the percentage of mentions of 'obedience' and 'independence' that respondents answered to the question: "which quality do you consider to be especially important to teach your children?". 5) The cultural dimension of competition emerges as the first component of a PCA in respondents' answers to the questions: "how would you place your view on a scale from 1 to 10", ranging from 'competition is good' to 'competition is harmful', and 'people can only get rich at the expense of others' versus 'wealth can grow so there is enough for everyone'. 6) Finally, the

\footnotetext{
${ }^{5}$ This overall measure of culture can be viewed as an aggregate indicator of a society's cultural background (Tabellini, 2010; Bützer et al., 2013; Kyriacou and López, 2015). Since this measure of overall culture (the first principal component) is positively correlated with four aspects of culture (trust, control, work and honesty) and negatively correlated with obedience and competition (see Table 2), we interpret it as a net measure of the traits of culture that favour labour productivity.
} 
cultural dimension of honesty arises as the first component of a PCA in respondents' answers to the questions: "Is it justifiable to cheat on taxes", "avoid fare on public transport" and "fail to report damage you have done accidentally to a parked vehicle?".

The data for labour productivity are drawn from the Organization for Economic Cooperation and Development (OECD) productivity database and refer to the average growth rate of GDP per hour worked in constant prices for the respective decade for each country (lpr) (e.g. Knack and Keefer, 1997; Hall and Jones, 1999). ${ }^{6}$ Following previous studies on the impact of culture on the macroeconomy (Knack and Keefer, 1997; Roth, 2009; Tabellini, 2010; Bützer et al., 2013; Bjornskov and Meon, 2015, among others), we include a number of macroeconomic and institutional variables as control variables. Specifically, vector $Z$ includes the real gross domestic product per capita $(g d p)$ as a measure of the level of income (e.g. Knack and Keefer, 1997; Knack, 2002; Roth, 2009), the level of trade openness (open) or the KOF globalization index $(k o f)$ as a measure of openness of the economy (e.g. Bjornskov and Meon, 2015; Barone and Mocetti, 2016), a measure of human capital (hcap) (e.g. Knack and Keefer, 1997; Zak and Knack, 2001; Roth, 2009; Tabellini, 2010), the level of government expenditures ( $g o v)$ as well as the level of government debt (debt) as measures of the public sector (e.g. Bjornskov and Meon, 2015), the level of inflation (inf) and the rate of unemployment (un) as measures of short-run macroeconomics (e.g. Barone and Mocetti, 2016), the quality of government ( $q \circ g$ ) as a measure of institutional quality and a measure of the confidence in national institutions (conf) (e.g. Tabellini, 2010; Bützer et al., 2013; Bjornskov and Meon, 2015; Kaasa 2016), a measure of government ideology (ideol) (e.g. Potrafke, 2017), and finally a measure of religiosity (relig) to control for any cultural impact of religion (e.g. Weber, 1958 [1904]; and Harrison and Huntington, 2000). ${ }^{7}$ The main source for the control variables is Bützer et al. (2013) except of the data for the unemployment rate that are obtained from the International Monetary Fund (IMF) World Economic Outlook (WEO) database, the trade openness data that are obtained from the Penn World Table (PWT) dataset, the KOF globalization index data that are obtained from the updated dataset of Dreher (2006), the government ideology data that are obtained from the updated dataset of

\footnotetext{
${ }^{6}$ In the robustness section, we present additional results using total factor productivity ( $f f p$ ) as an alternative proxy of productivity (Bjornskov and Meon, 2015). The data for the measure of total factor productivity are obtained from the Penn World Table (PWT) dataset.

${ }^{7}$ Following the literature (Tabellini, 2010; Bützer et al., 2013; Bjornskov and Meon, 2015; Kaasa, 2016, among others), we include those two measures of the quality and the confidence in institutions to control for any potential indirect impact of culture on productivity through the channel of institutions, and thus, to identify the exact effect of culture on labour productivity beyond the influence of institutions.
} 
Beck et al. (2001), and the data for the human capital measure (i.e. the average years of schooling) that are obtained from the Barro and Lee (2013) dataset.

Table 1 provides the descriptive statistics of all the variables used in the analysis, while Table 2 provides the correlation matrix between the overall measure of culture and the six alternative cultural dimensions.

\section{Insert Tables $1 \& 2$ here}

We observe that the overall culture measure is positively correlated with four traits of culture (trust, control, work and honesty) and negatively correlated with obedience and competition, reaffirming the previous evidence by Tabellini (2010) and Kyriacou and López (2015) using cross-sectional data.

\section{EMPIRICAL RESULTS}

An initial graphical investigation of the correlation between the overall measure of culture with the labour productivity, as measured by the average growth rate of GDP per hour worked, is given in Figure 1.

\section{Insert Figure 1 here}

Figure 1 provides a first indication of the positive association between culture and labour productivity for the 34 OECD countries over the last three decades. ${ }^{8}$

In extension to previous cross-country studies that explore the impact of culture on various macroeconomic variables, we adopt a panel approach to investigate the association of culture with labour productivity. Our analysis continues with the estimation of alternative specifications of Equation (1) for the panel of the 34 OECD countries over the last three decades.

In Table 3, we provide evidence, using a baseline version of the specification of Equation (1), without including any control variables, on the relationship between the overall measure of culture - as well as the six alternative traits of the cultural background -with the

\footnotetext{
${ }^{8}$ The fitted line is based on the regression model of Equation (1), including the level of GDP per capita as control variable and allowing for both country and year fixed effects.
} 
productivity of labour, using the two-way fixed effects method allowing for both country and decade specific effects that capture the unobserved characteristics across countries as well as over time.

\section{Insert Table 3 here}

The results from the simple bivariate specification, reported in Table 3, show that the coefficient of the overall measure of culture is positive and statistically significant; highlighting that the cultural background of a society is associated with higher labour productivity growth. The estimate on overall culture (0.997) shows that a one-standard deviation change in culture will lead to about a one-standard deviation increase in labour productivity growth for the OECD countries. Our evidence is consistent with previous crosscountry studies (Bjornskov and Meon, 2015; Kaasa, 2016) on the positive association of social capital with productivity. The overall measure of culture captures a variety of cultural values or norms of a society (Guiso et al., 2006; Tabellini, 2010). To explore the impact of the various dimensions of a society's civic culture on labour productivity we identify six distinct cultural traits, namely: interpersonal trust, control, work ethic, obedience, competition affinity and honesty. We observe that all cultural measures have the expected sign (except honesty), confirming the view of Tabellini (2010), however, only work and obedience are found to be statistically significant. This indicates that the main channel of the positive relationship of culture on productivity stems from the work ethic measure, while obedience affects negatively labour productivity (as expected, since obedience is strongly negatively correlated with the overall cultural measure).

We continue, following the previous empirical literature (Knack and Keefer, 1997; Tabellini, 2010; Bützer et al., 2013; Bjornskov and Meon, 2015; among others), and extend the regression specification between the alternative measures of culture and the productivity of labour by including a number of macroeconomic and institutional variables as control variables. Therefore, we isolate the impact of culture on labour productivity by controlling for several confounding factors capturing the effect of the macroeconomic environment and the institutional background. In Table 4 we extend the empirical setting by adding only the real per capita GDP ( $g d p)$ as the main control variable in our specification, while in Table 5 we start with the parsimonious specification used in Table $\mathbf{4}$ and extend the model by including additional control variables proposed in the literature. 


\section{Insert Table 4 here}

The results from Table 4 clearly confirm the positive association between culture and productivity of labour, albeit the impact is smaller in size but remains significant, and demonstrate as the main channels for this link the control and the work ethic environment dimensions, while obedience continues its significant negative impact on productivity. The estimate on overall culture (0.802) - when controlling for the per capita output - shows that a change in culture by one-standard deviation will increase labour productivity growth by about $4 / 5$ of a standard deviation.

Following the literature, and in order to explore the sensitivity of our results on the association between culture and labour productivity, and control for any potential indirect impact of culture through the macroeconomicand the institutional environment of a society on productivity, we proceed by including additional control variables and employing alternative specifications of Equation (1). Table 5 shows the results of various specifications, where we include vector $Z$, containing further control variables (besides the per capita output $(g d p))$. Specifically, we include several potential relevant macroeconomic and institutional variables such as the level of trade openness (open) or the KOF index of globalization (kof), a measure of human capital (i.e. the average years of schooling) (hcap), the level of government expenditures ( $g o v)$, the level of government debt (debt), the inflation rate (inf), the unemployment rate (un), a measure of the quality of institutions ( $q \circ g$ ), a measure of the confidence in national institutions (conf), a measure of government ideology (ideol), and a measure of religiosity (relig).

\section{Insert Table 5 here}

The results from Table 5, show that the positive effect of the cultural background on labour productivity remains stable across different control variables and alternative specifications. Specifically, column 1 shows the baseline specification with only the per capita output as the main control variable (repeating column 1 from Table 4). Column 2-6 augments the specification with the trade openness (or the KOF globalization index) and human capital as additional controls. In columns 7-8 we extend the specification by controlling for the impact of the public sector, while in columns 9-10 we control for the impact of short-run macroeconomic factors such as the inflation rate and the unemployment rate. In columns 11-12 and 15 we control for the impact of institutions, while in column 13 
we control for the impact of government ideology and in column 14 for the impact of religion. Finally, in columns 16-19 we augment the standard specification with various macroeconomic and institutional factors. The coefficient of the overall measure of culture have the expected positive sign and is statistically significant in all alternative specifications, however the magnitude of the impact is found to be sensitive on the choice of the control variables, ranging from 0.374 (column 8) to 1.249 (column 19). Finally, the non-significance of both measures of the quality and the confidence in institutions suggests that culture have a direct effect on labour productivity that is not intermediated through the institutional background. This confirms previous views that culture has a direct effect on economic performance (e.g. Zak and Knack, 2001; Sabatini, 2008; Tabellini, 2008; 2010; among others) and provides new insights on a direct impact on productivity.

Extending Table 4, we explore the impact of the alternative aspects of culture on the labour productivity by including to the estimation Equation (1) additional control variables (in addition to the level of real GDP per capita, we add the level of openness and the measure of human capital in the specification). ${ }^{9}$ The results are provided in Table 6.

\section{Insert Table 6 here}

The results in Table 6 confirm the outcome of Table 5 and support the view that the main sources of the positive impact of culture on productivity comes from the control and the work ethic environment, while the impact of obedience remains negative and significant. The estimate of overall culture (0.880) shows that a positive change of the cultural background in an economy (by one-standard deviation) will increase labour productivity by around 0.9 of a standard deviation. This is significantly lower than the estimate (1.249) with the full set of controls (column 19 of Table 5) but is slightly higher than the estimate when controlling only for the level of per capita GDP (column 1 of Table 5).

\footnotetext{
${ }^{9}$ Our results are robust to alternative sets of control variables. For example, we have extended the set of control variables by adding to our standard specification (which includes the level of real GDP per capita, the level of openness and the human capital measure) the measures for the quality of institutions and the confidence in national institutions with qualitatively similar findings. These results are available from the authors upon request.
} 


\subsection{Robustness Checks}

We check the robustness of our main results by employing a number of robustness tests regarding a) the grouping of the countries under consideration, b) the use of standardized measures of cultural variables, and c) the model specification. ${ }^{10}$

We start the robustness tests by exploring the culture-productivity relationship across alternative country sub-samples of the data in Table 7.

\section{Insert Table 7 here}

From Table 7 we observe that the positive link between culture and productivity is robust across alternative grouping of countries. Furthermore, the magnitude of the impact of culture on labour productivity increases when we rely on more homogeneous country samples (e.g. the Europe, EU and EA12 groups). This is an indication that countries with similar cultural characteristics display higher productivity growth, confirming the view of Zak and Knack (2001) that more homogeneous societies exhibit higher trust, and thereby higher levels of investment and growth.

We next continue, by replicating Table 6 and exploring the impact of the alternative measures of culture on labour productivity using the standardized measures of the cultural variables (which account for differences in the variance) as discussed in Bützer et al. (2013) (Table 8). The results confirm the outcome of Table 6 and show that the choice of the cultural measure (standardized or non-standardized) does not affect the results, reaffirming the findings of Bützer et al. (2013).

\section{Insert Table 8 here}

In addition, we explore the robustness of our results by examining alternative model specifications of Equation (1) (Table 9). We extend the standard panel data specification by employing a dynamic panel data model that includes lagged productivity as an explanatory variable. Specifically, along with the benchmark two-way fixed effects estimator, which

${ }^{10}$ Our results are also robust to alternative estimation methods. Besides the fixed effects (FE) estimation, we have employed both a pooled OLS (POLS) and a random effects (RE) estimation method. The main findings using these alternative estimation methods remain unaltered. These results are available from the authors upon request. 
controls for both country-specific and decade-specific fixed effects (column 2), we employ the one-way fixed effects model (i.e., including only country-specific fixed effects) (column 1), and then we move to the dynamic panel data specifications which allow for the presence of one lag of the dependent variable as explanatory variable (i.e., using a first order autoregressive setting, $A R(1)$ ). We use both the dynamic fixed effects (DFE) estimator as well as the bias corrected fixed effects (BCFE) estimation method, as suggested by Bruno (2005), for robustness purposes. ${ }^{11}$ From Table 9 we can confirm the robustness of the positive relationship between culture and labour productivity over alternative model specifications and estimation methods.

\section{Insert Table 9 here}

Finally, we examine the robustness of the previous findings by examining a different measure of productivity (Table 10). ${ }^{12}$ Following Bjornskov and Meon (2015), we use the measure of total factor productivity $(t f p)$ as an alternative proxy of productivity in the economy.

\section{Insert Table 10 here}

From Table 10 we can confirm the robustness of the positive association between culture and productivity over alternative specifications and estimation methods. The correlation between culture and productivity (as measured by the total factor productivity) is positive and remains significant in most of the alternative specifications employed. The results reaffirm our findings of a positive relationship between the cultural background and productivity that remains robust to alternative measures of productivity.

The overall evidence from our analysis shows a significant positive link between culture and labour productivity and corroborates with previous cross-country studies such as

\footnotetext{
${ }^{11}$ The presence of lagged productivity in the specification results in a biased FE estimator when $T$ is fixed. Kiviet (1995) proposes a bias corrected Fixed Effects estimator to estimate the dynamic panel model. Bruno (2005) extends the bias corrected FE approach and provide approximation formulas and a bootstrap variance covariance matrix for the corrected estimator. Specifically, the BCFE method used here is initialized by employing first a dynamic panel estimate (the AB-GMM estimator) and then employ a recursive correction of the bias of the FE estimator. We have also estimated the dynamic panel model using the AB-GMM estimator with similar findings. These results can be provided upon request. We would like to thank an anonymous referee for drawing our attention to this point.

${ }^{12} \mathrm{We}$ thank an anonymous referee for this suggestion.
} 
Bjornskov and Meon (2015) and Kaasa (2016) on the positive relationship between social trust and productivity.

\section{CONCLUSIONS}

In this paper, the relationship between the cultural background of a society and labour productivity is examined. Using a panel dataset of 34 OECD countries over a period of three decades, and a fixed effects estimation approach, the analysis suggests a significant positive association between culture and labour productivity. More precisely, throughout the empirical analysis, a positive impact of cultural background on labour productivity is highlighted that is robust to a number of robustness checks. The positive link is supported by a simple regression between culture and labour productivity (without including any control variables) and remains stable after using GDP per capita as the main control variable, as well as when adding various macroeconomic and institutional factors as further control variables. In addition, the positive nexus is confirmed across alternative country groupings, when using the standardized measures for the cultural variables, or when using alternative proxies for productivity. Finally, the results are robust when employing alternative specification forms, including a dynamic panel model, along with the benchmark fixed effects model.

The main channels for the positive association between culture and labour productivity, are the control and work ethic environment, while obedience seems to have a negative effect on labour productivity. These results show that labour productivity is higher in societies in which $a$ ) there is a belief in individual self-determination, referring to individuals' conviction that their life is primarily controlled by themselves rather than by exogenous factors and that individual effort is likely to pay off, $b$ ) hard work is very important for individuals and especially important as a value to be taught to their children, $c$ ) individuals deal relatively more often with strangers and more often with friends or members of their family, and $d$ ) independence is assumed to be considered as an especially important value to be taught to the children.

On policy grounds, the conclusions derived throughout the analysis can be used from policy makers which need to confront issues that arise when cultural values in the societies impede productivity growth. For instance, policy makers can enhance the freedom of choice and control how people feel about their life turns out (control of life), through developing a 
safer environment, since this is a strong motivation in order to work harder, to innovate and to undertake new economic initiatives (Tabellini, 2010). Furthermore, policy makers and business managers should be concentrated to create a better business environment, that will provide more incentives to firms, in which the intrinsic motivation to work (work ethic) will be higher. Lastly, independence of the members in the society needs to be increased, although a certain level of obedience is necessary for the acceptance of decisions taken and a better function in the working procedures through cooperation.

Having certified a strong and significant positive relationship between the cultural background and productivity, it is reasonable to think about whether the productivity slowdown that is observed over the past two decades in the western world (Gordon, 2012; Eichengreen et al., 2017) may be attributed to the change of key cultural background variables. Thus, a proposal for future research could be related to the fact that $a$ ) globalization and its consequences (population movements, unequal distribution of income, social mobility retardation), and $b$ ) population aging, may be regarded as major reasons for an adverse change in cultural values that promote productivity, such as the production of uncertainty avoidance behaviour, reduced social trust level, etc. The simultaneous operation of these factors, as well as the simultaneous operation of other factors (such as the financial consequences of the Great Recession) may lead to a negative cultural impact on productivity. Future research could therefore examine whether these factors are responsible for stimulating the productivity slowdown in OECD economies. 


\section{REFERENCES}

Acemoglu, D. (2009) Introduction to Modern Economic Growth, Massachusetts: MIT Press.

Agénor, P.R., and O. Canuto (2015) 'Middle-income Growth Traps', Research in Economics, 69(4): 641-660.

Alesina, A., P. Giuliano and N. Nunn (2013) 'On the Origins of Gender Roles: Women and The Plough', Quarterly Journal of Economics, 128(2): 469-530.

Bandiera, O, I. Barankay and I. Rasul (2010) 'Social Incentives in the Workplace', Review of Economic Studies, 77: 417-459.

Barone, G. and S. Mocetti (2016) 'Inequality and Trust: New Evidence from Panel Data', Economic Inquiry, 54(2): 794-809.

Barro, R. and J.W. Lee (2013) 'A New Data Set of Educational Attainment in the World, 1950-2010', Journal of Development Economics, 104: 184-198.

Beck, T., Clarke, G., Groff, A., Keefer, P., and Walsh, P. (2001) 'New Tools in Comparative Political Economy: The Database of Political Institutions', The World Bank Economic Review, 15(1): 165-176.

Bjornskov, C. and P.G. Meon (2015) 'The Productivity of Trust', World Development, 70: 317-331.

Bruno, G.S. (2005) 'Approximating the Bias of the LSDV Estimator for Dynamic Unbalanced Panel Data Models', Economics Letters, 87: 361-366.

Bützer, S., C. Jordan and L. Stracca (2013) Macroeconomic Imbalances: A Question of Trust?, Working Paper 1584, European Central Bank.

Ciavarella, M.A. (2003) 'The Adoption of High-Involvement Practices and Processes in Emergent and Developing Firms: A Descriptive and Prescriptive Approach', Human Resource Management, 42(4): 337-356.

Cox, P.L., B.A. Friedman and T. Tribunella (2011) 'Relationships among Cultural

Dimensions, National Gross Domestic Product, and Environmental Sustainability', Journal of Applied Business and Economics, 12(6): 46-56.

De Grip, A. and J. Sauermann (2012) 'The Effects of Training on Own and Co-worker Productivity: Evidence from a Field Experiment', Economic Journal, 122: 376-399.

De Jong, E. (2009) Culture and Economics: On Values, Economics, and International Business, London: Routledge.

De Jong, E. (2011) 'Culture, Institutions and Economic Growth', Journal of Institutional Economics, 7(4): 523-527. 
Dearmon, J. and R. Grier (2009) 'Trust and Development', Journal of Economic Behavior and Organization, 71: 210-220.

Denison, D.R. (1996) 'What is the Difference Between Organizational Culture and Organizational Climate? A Native's Point of View on a Decade of Paradigm Wars', Academy of Management Review, 21(3): 619-654.

Dreher, A. (2006) 'Does Globalization Affect Growth? Evidence from a New Index of Globalization', Applied Economics, 38: 1091-1110.

Economides, G. and P.H. Egger (2009) 'The Role of Institutions in Economic Outcomes: Editorial Introduction', European Journal of Political Economy, 25(3): 277-279.

Eichengreen, B., D. Park and K. Shin (2012) 'When Fast Growing Economies Slow Down: International Evidence and Implications for China', Asian Economic Papers, 11(1): 4287.

Eichengreen, B., D. Park and K. Shin (2017) 'The Global Productivity Slump: Common and Country-specific Factors', Asian Economic Papers, 16(3): 1-41.

Erez, M. and A. Somech (1996) 'Is Group Productivity Loss the Rule or The Exception?

Effects of Culture and Group Based Motivation', Academy of Management Journal, 39(6): 1513-1537.

Falk, A. and A. Ichino (2006) 'Clean Evidence on Peer Effects', Journal of Labor Economics, 24: 39-57.

Fang, Z., X. Xu, L.W. Grant, J.H. Stronge and T.J. Ward (2016) 'National Culture, Creativity, and Productivity: What's the Relationship with Student Achievement?', Creativity Research Journal, 28(4): 395-406.

Fenton-O'Creevy, M. (1998) 'Employee Involvement and the Middle Manager: Evidence from a Survey of Organisations', Journal of Organisational Behaviour, 19(1): 67-84.

Fukuyama, F. (1995) Trust: The Social Virtues and the Creation of Prosperity, New York: Free Press.

Gaganis C., F. Pasiouras, and F. Voulgari (2019) 'Culture, Business Environment and SMEs' Profitability: Evidence from European Countries', Economic Modelling, 78: 275-292.

Gasper, D. (1996) 'Culture and Development Ethics: Needs, Women's Rights, and Western Theories', Development and Change, 27(4): 627-661.

Goncalo, J.A and B.M. Staw (2006) 'Individualism-Collectivism and Group Creativity', Journal of Organisational Behaviour and Human Decision Processes', 100(1): 96-109.

Gordon, R. (2012) Is US Economic Growth Over? Faltering Innovation Confronts the Six Headwinds, NBER Working Paper No. 18315. 
Guiso, L., P. Sapienza and L. Zingales (2006) 'Does Culture Affect Economic Outcomes?', Journal of Economic Perspectives, 20: 23-48.

Guiso, L., P. Sapienza and L. Zingales (2015) 'Corporate Culture, Societal Culture, and Institutions', American Economic Review: Papers \& Proceedings, 105(5): 336-339.

Hall, R.E. and C.I. Jones (1999) 'Why Do Some Countries Produce So Much More Output Per Worker Than Others?', Quarterly Journal of Economics, 114: 83-116.

Harrison, L.E. and S.P. Huntington (2000) Culture Matters: How Values Shape Human Progress, New York: Basic Books.

Hofstede, G. (1980) Culture's consequences: international differences in work-related values. Beverly Hills, CA: Sage Publications.

Hofstede, G., G.J. Hofstede and M. Minkov (2010) Cultures and Organizations: Software of the Mind. New York: McGraw-Hill.

House, R.J., P.J. Hanges, M. Javidan, P.W. Dorfman and V. Gupta (2004) Culture, leadership and organisations - the GLOBE study of 62 societies. Thousand Oaks, CA: Sage Publications.

Johnston, L. (1996) 'Resisting Change: Information-Seeking and Stereotype Change', European Journal of Social Psychology, 26: 799-825.

Kaasa, A. (2016) 'Social Capital, Institutional Quality and Productivity: Evidence from European Regions', Economics \& Sociology, 9(4): 11-26.

Kiviet, J.F. (1995) 'On Bias, Inconsistency, and Efficiency of Various Estimators in Dynamic Panel Data Models', Journal of Econometrics, 68: 53-78.

Knack, S. (2002) 'Social Capital and the Quality of Government: Evidence from the States', American Journal of Political Science, 46(4): 772-785.

Knack, S. and P. Keefer (1997) 'Does Social Capital Have an Economic Pay-Off? A CrossCountry Investigation', Quarterly Journal of Economics, 112: 1251-1288.

Kopelman, R.E., A.P. Brief and R.A. Guzzo (1990) 'The Role of Climate and Culture in Productivity', in S. Benjamin (Ed.), Organisational Climate and Culture, San Francisco: Jossey-Bass.

Kreps, D.M. (1990) 'Corporate Culture and Economic Theory', in E.A. James and A.S. Kenneth (Eds.), Perspectives on Positive Political Economy, Cambridge: Cambridge University Press.

Kyriacou, A.P. and F.J. López (2015) 'Inequality and Culture in a Cross-Section of Countries', Journal of Institutional Economics, 11(1): 141-166. 
La Porta, R., F. Lopez-de-Silanes, A. Shleifer and R. Vishny (1997) 'Trust in Large Organizations', American Economic Review, 87: 333-338.

Leibenstein, H. (1982) 'The Prisoner's Dilemma in the Invisible Hand: An Analysis of Intrafirm Productivity', American Economic Review, 72(2): 92-97.

Machiavelli, N. [1519] (1987) Discourses on Livy, New York: Oxford University Press.

Marcén, M. (2014) 'The Role of Culture on Self-Employment', Economic Modelling, 44(S1): S20-S32.

Marshall, A. [1890] (1997) Principles of Economics. New York: Prometheus Books.

Martinez, E.A., N. Beaulieu, R. Gibbons, P. Pronovost and T.Wang (2015) 'Organizational

Culture and Performance', American Economic Review: Papers \& Proceedings, 105(5): 331-335.

Mas, A. and E. Moretti (2009) 'Peers at Work', American Economic Review, 99(1): 112-145.

Mathew, J. (2007) 'The Relationship of Organisational Culture with Productivity and Quality', Employee Relations, 29(6): 677-695.

Montesquieu, C. de Secondat [1748] (1989) The Spirit of the Laws, Translated and edited by Anne M. Cohler, B. C. Miller and H. S. Stone. New York: Cambridge University Press.

Paldam, M. (2011) 'Generalized Trust: The Macro Perspective', in L. Sacconi and G.D. Antoni (Eds.), Social Capital, Corporate Social Responsibility, Economic Behaviour and Performance, London: Palgrave Macmillan.

Patterson, M., P. Warr, and M. West (2004) 'Organisational Climate and Company Productivity: The Role of Employee Affects and Employee Level', Journal of Occupational and Organisational Psychology, 77(2): 193-216.

Petrakis, P.E. (2014) Culture, Growth and Economic Policy; From the Question to Exploration, New York and Heidelberg: Springer.

Petrakis, P.E. and P.C. Kostis (2013) 'Economic Growth and Cultural Change', Journal of Socio-Economics, 47(C): 147-157.

Pham, H.T., F. Carmignani, and P. Kler (2018) 'Thrift Culture and the Size of Government', Economic Modelling, 70: 571-578.

Potrafke, N. (2017) 'Partisan Politics: The Empirical Evidence from OECD Panel Studies', Journal of Comparative Economics, 45(4): 712-750.

Putnam, R.D. (1993) Making Democracy Work. Civic Traditions in Modern Italy. Princeton: Princeton University Press. 
Ramos, P. and J.A. Paiva (2017) 'Dedication Increases Productivity: An Analysis of the Implementation of a Dedicated Medical Team in the Emergency Department', International Journal of Emergency Medicine, 10(1): 1-8.

Roth, F. (2009) 'Does Too Much Trust Hamper Economic Growth?', Kyklos, 62(1), 103-128.

Sabatini, F. (2008) 'Social Capital and the Quality of Economic Development', Kyklos, 61(3): 466-499.

Schwarz, S.H. (2009) 'Culture Matters: National Value Cultures, Sources, and Consequences', in R.S. Wyer et al. (Eds.), Understanding Culture, New York: Psychology Press.

Siehl, C. and J. Martin (1990) 'Organisational Culture: A Key to Financial Performance', in B. Schneider (Ed.), Organisational Climate and Culture, San Francisco: Jossey-Bass.

Stivers, R. (1994) The Culture of Cynicism, Oxford: Blackwell.

Tabellini, G. (2008) 'Institutions and Culture', Journal of the European Economic Association, 6(2): 255-294.

Tabellini, G. (2010) 'Culture and Institutions: Economic Development in The Regions of Europe', Journal of the European Economic Association, 8(4): 677-716.

Throsby, D. (2001) Economics and Culture, Cambridge: Cambridge University Press.

Weber, M. [1904] (1958) The Protestant Ethic and the Spirit of Capitalism, New York: Scribner.

Whiteley, P. (2000) 'Economic Growth and Social Capital', Political Studies, 48: 443-466.

Xue, M. and W. Cheng (2013) 'National Culture, Market Condition and Market Share of Foreign Bank', Economic Modelling, 33: 991-997.

Zak, P.J. and S. Knack (2001) 'Trust and Growth', Economic Journal, 111: 295-321.

Zhou, X., Y. Cui, S. Wu, and W. Wang (2019), 'The Influence of Cultural Distance on the Volatility of the International Stock Market', Economic Modelling, 77: 289-300. 


\section{TABLES AND FIGURES}

Table 1. Descriptive Statistics

\begin{tabular}{lrrrrr}
\hline & Mean & SD & Min & Max & Obs \\
\hline culture & 0.223 & 1.376 & -3.577 & 3.414 & 84 \\
trust & 3.490 & 1.405 & 0.884 & 7.016 & 86 \\
control & 6.928 & 0.595 & 5.080 & 8.012 & 84 \\
work & -0.069 & 1.023 & -2.188 & 1.932 & 86 \\
obedience & -0.240 & 1.019 & -2.344 & 1.581 & 86 \\
competition & -0.079 & 0.907 & -1.966 & 2.742 & 67 \\
honesty & -0.021 & 1.213 & -5.441 & 1.770 & 86 \\
lpr & 2.091 & 1.313 & -0.014 & 7.611 & 83 \\
tfp & 0.942 & 0.091 & 0.664 & 1.191 & 98 \\
gdp & 9.973 & 0.514 & 8.446 & 11.189 & 99 \\
open & 4.199 & 0.524 & 2.919 & 5.663 & 98 \\
kof & 4.280 & 0.158 & 3.849 & 4.487 & 98 \\
hcap & 2.870 & 0.357 & 1.781 & 3.573 & 100 \\
gov & 2.947 & 0.206 & 2.431 & 3.290 & 53 \\
debt & 0.536 & 0.298 & 0.054 & 1.634 & 83 \\
inf & 1.744 & 0.752 & -0.323 & 3.904 & 98 \\
un & 1.804 & 0.638 & -0.803 & 2.956 & 98 \\
qog & 0.831 & 0.153 & 0.476 & 1.000 & 91 \\
conf & 0.187 & 1.056 & -1.895 & 4.495 & 67 \\
ideol & 1.955 & 0.670 & 1.000 & 3.000 & 95 \\
relig & -0.397 & 1.049 & -2.532 & 1.627 & 86 \\
\hline Notes: Summat & stat & & & \\
\end{tabular}

Notes: Summary statistics for the unbalanced sample, based on $N_{\max }=34$ countries and

$T_{\max }=3$ decades. The abbreviations stand for the following: lpr: labour productivity growth, $t f p$ : total factor productivity growth, $g d p$ : real GDP per capita, open: the level of trade openness, kof: the KOF globalization index, hcap: human capital measure, gov: the level of government expenditures, debt: the level of government debt, inf: inflation rate, un: rate of unemployment, qog: institutional quality, conf: confidence in national institutions, ideol: government ideology, and relig: measure of religiosity. All cultural variables are non-standardized and are defined in the data section. 
Table 2. Correlation Matrix of Culture and Alternative Dimensions of Culture

\begin{tabular}{llllllll}
\hline & culture & trust & control & work & obedience & competition & honesty \\
\hline culture & 1.000 & & & & & & \\
trust & 0.666 & 1.000 & & & & & \\
control & 0.553 & 0.463 & 1.000 & & & & \\
work & 0.744 & 0.183 & 0.261 & 1.000 & & & \\
obedience & -0.819 & -0.441 & -0.160 & -0.584 & 1.000 & & \\
competition & -0.422 & -0.271 & -0.327 & -0.451 & 0.111 & 1.000 & \\
honesty & 0.371 & 0.459 & 0.166 & 0.096 & -0.188 & -0.510 & 1.000 \\
\hline
\end{tabular}

Notes: Correlations for the unbalanced sample, based on $N_{\max }=34$ countries and $T_{\max }=3$ decades. Culture is constructed as the first principal component of the alternative cultural variables. All cultural variables are nonstandardized. 
Table 3. Culture and Labour Productivity (Alternative Dimensions of Culture)

\begin{tabular}{|c|c|c|c|c|c|c|c|}
\hline & (1) & (2) & (3) & (4) & (5) & (6) & (7) \\
\hline culture & $\begin{array}{l}0.997 * * \\
(2.99)\end{array}$ & & & & & & \\
\hline trust & & $\begin{array}{l}0.064 \\
(0.21)\end{array}$ & & & & & \\
\hline control & & & $\begin{array}{l}1.232 \\
(1.36)\end{array}$ & & & & \\
\hline work & & & & $\begin{array}{c}1.186^{* *} \\
(3.34)\end{array}$ & & & \\
\hline obedience & & & & & $\begin{array}{c}-0.882 * * \\
(-2.54)\end{array}$ & & \\
\hline competition & & & & & & $\begin{array}{l}0.141 \\
(0.46)\end{array}$ & \\
\hline honesty & & & & & & & $\begin{array}{l}-0.089 \\
(-0.26)\end{array}$ \\
\hline Obs & 74 & 76 & 74 & 76 & 76 & 59 & 76 \\
\hline$R^{2}$ & 0.503 & 0.375 & 0.428 & 0.468 & 0.467 & 0.401 & 0.377 \\
\hline$N$ & 33 & 34 & 33 & 34 & 34 & 34 & 34 \\
\hline$T$ & 2.242 & 2.235 & 2.242 & 2.235 & 2.235 & 1.735 & 2.235 \\
\hline
\end{tabular}

Notes: $t$-statistics in parentheses. ${ }^{*}$ and ${ }^{* *}$ denotes significance at the 10 per cent and 5 per cent significance levels, respectively. All estimations were carried out using the Fixed Effects method allowing for both country and decade specific effects with cluster-robust standard errors. 
Table 4. Culture and Labour Productivity (Alternative Dimensions of Culture)

- Including the log of Real GDP per Capita as Control Variable

\begin{tabular}{|c|c|c|c|c|c|c|c|}
\hline & (1) & (2) & (3) & (4) & (5) & (6) & (7) \\
\hline culture & $\begin{array}{l}0.802 * * \\
(2.18)\end{array}$ & & & & & & \\
\hline trust & & $\begin{array}{l}-0.190 \\
(-0.85)\end{array}$ & & & & & \\
\hline control & & & $\begin{array}{c}1.528 * * \\
(2.26)\end{array}$ & & & & \\
\hline work & & & & $\begin{array}{c}0.821 * * \\
(2.13)\end{array}$ & & & \\
\hline obedience & & & & & $\begin{array}{c}-0.635 * * \\
(-2.05)\end{array}$ & & \\
\hline competition & & & & & & $\begin{array}{l}0.203 \\
(0.72)\end{array}$ & \\
\hline honesty & & & & & & & $\begin{array}{l}0.013 \\
(0.04)\end{array}$ \\
\hline$g d p$ & $\begin{array}{l}-2.015^{* *} \\
(-2.21)\end{array}$ & $\begin{array}{l}-2.985^{* *} \\
(-3.56)\end{array}$ & $\begin{array}{l}-3.212 * * \\
(-3.86)\end{array}$ & $\begin{array}{l}-2.113 * * \\
(-2.34)\end{array}$ & $\begin{array}{l}-2.174 * * \\
(-3.72)\end{array}$ & $\begin{array}{l}-4.319 * * \\
(-2.65)\end{array}$ & $\begin{array}{l}-2.809 * * \\
(-3.37)\end{array}$ \\
\hline Obs & 74 & 76 & 74 & 76 & 76 & 59 & 76 \\
\hline$R^{2}$ & 0.554 & 0.487 & 0.568 & 0.520 & 0.525 & 0.512 & 0.482 \\
\hline$N$ & 33 & 34 & 33 & 34 & 34 & 34 & 34 \\
\hline$T$ & 2.242 & 2.235 & 2.242 & 2.235 & 2.235 & 1.735 & 2.235 \\
\hline
\end{tabular}


Table 5. Culture and Labour Productivity (Robustness over Control Variables)

\begin{tabular}{|c|c|c|c|c|c|c|c|c|c|c|c|c|c|c|c|c|c|c|c|}
\hline & (1) & (2) & (3) & (4) & (5) & (6) & (7) & (8) & (9) & $(10)$ & $(11)$ & (12) & (13) & (14) & (15) & (16) & (17) & $(18)$ & (19) \\
\hline \multirow[t]{2}{*}{ culture } & $0.802^{* * *}$ & $0.949^{* *}$ & $0.802^{* *}$ & $0.741^{*}$ & $0.880^{* *}$ & $0.732^{*}$ & $1.045^{*}$ & $0.374^{*}$ & $0.900^{* * *}$ & $0.879^{* * *}$ & $0.999^{* * *}$ & $1.087^{* *}$ & $0.841^{* *}$ & $0.912^{* *}$ & $1.079^{* *}$ & $0.865^{* *}$ & $1.018^{* * *}$ & $1.166^{* *}$ & $1.249^{* *}$ \\
\hline & $(2.18)$ & $(3.65)$ & $(2.16)$ & (1.90) & $(3.21)$ & $(1.87)$ & (1.97) & $(1.72)$ & $(3.21)$ & $(2.98)$ & $(2.67)$ & $(2.53)$ & $(4.23)$ & $(3.12)$ & $(2.56)$ & (2.69) & $(2.59)$ & $(2.56)$ & $(3.00)$ \\
\hline \multirow[t]{2}{*}{$g d p$} & $-2.015^{* *}$ & $-1.878^{* *}$ & -2.128 & $-2.069^{* *}$ & $-1.937^{* *}$ & $-2.295^{*}$ & -1.384 & $-4.288^{* *}$ & $-2.030^{* *}$ & $-1.932^{* *}$ & -1.822 & -0.001 & $-2.387^{* *}$ & $-1.775^{* *}$ & 0.969 & $-1.937^{* *}$ & -1.868 & -0.484 & -1.782 \\
\hline & $(-2.21)$ & $(-2.19)$ & $(-1.66)$ & $(-2.51)$ & $(-2.40)$ & $(-1.95)$ & $(-1.14)$ & $(-2.70)$ & $(-2.30)$ & $(-2.54)$ & $(-0.90)$ & $(-0.00)$ & $(-2.97)$ & $(-2.61)$ & $(0.49)$ & $(-2.56)$ & $(-0.87)$ & $(-0.14)$ & $(-0.52)$ \\
\hline \multirow[t]{2}{*}{ open } & & $3.427^{* *}$ & & & $3.577^{* *}$ & & $4.223^{* * *}$ & $2.834^{* *}$ & $3.719^{* *}$ & $3.577^{* *}$ & $2.542^{*}$ & $3.378^{* *}$ & $3.393^{* * *}$ & $3.663^{* *}$ & $3.627^{* *}$ & $3.758^{* * *}$ & $2.712^{*}$ & $3.704^{* *}$ & $3.160^{*}$ \\
\hline & & $(2.53)$ & & & $(3.10)$ & & (3.38) & $(3.61)$ & $(3.16)$ & $(3.07)$ & $(1.75)$ & $(2.54)$ & $(3.36)$ & $(3.10)$ & $(2.33)$ & $(3.21)$ & (1.76) & $(2.17)$ & (1.92) \\
\hline \multirow[t]{2}{*}{ kof } & & & 0.800 & & & 1.558 & & & & & & & & & & & & & \\
\hline & & & $(0.25)$ & & & $(0.49)$ & & & & & & & & & & & & & \\
\hline \multirow[t]{2}{*}{ hcap } & & & & -1.012 & $-1.243^{*}$ & -1.147 & -2.563 & $-1.988^{* *}$ & $-1.268^{*}$ & $-1.246^{*}$ & -1.088 & -1.410 & $-1.360^{* *}$ & $-1.378^{* *}$ & -1.480 & $-1.346^{*}$ & -0.988 & -1.277 & -0.828 \\
\hline & & & & $(-1.28)$ & $(-1.91)$ & $(-1.33)$ & $(-1.44)$ & $(-2.95)$ & $(-1.82)$ & $(-1.93)$ & $(-0.95)$ & $(-1.25)$ & $(-2.12)$ & $(-2.07)$ & $(-1.33)$ & $(-1.86)$ & $(-0.88)$ & $(-1.11)$ & $(-0.59)$ \\
\hline \multirow[t]{2}{*}{ gov } & & & & & & & 1.204 & & & & & & & & & & & & \\
\hline & & & & & & & $(0.38)$ & & & & & & & & & & & & \\
\hline \multirow[t]{2}{*}{$d e b t$} & & & & & & & & $-1.578^{* *}$ & & & & & & & & & & & \\
\hline & & & & & & & & $(-2.61)$ & & & & & & & & & & & \\
\hline \multirow[t]{2}{*}{ inf } & & & & & & & & & 0.211 & & & & & & & 0.278 & 0.187 & 0.195 & 0.152 \\
\hline & & & & & & & & & $(0.82)$ & & & & & & & $(0.80)$ & $(0.50)$ & $(0.41)$ & $(0.32)$ \\
\hline \multirow[t]{2}{*}{ un } & & & & & & & & & & 0.006 & & & & & & 0.152 & 0.003 & -0.239 & -0.514 \\
\hline & & & & & & & & & & $(0.02)$ & & & & & & $(0.36)$ & $(0.01)$ & $(-0.45)$ & $(-0.75)$ \\
\hline \multirow[t]{2}{*}{$q o g$} & & & & & & & & & & & 0.833 & & & & -2.120 & & 0.795 & -0.454 & 1.378 \\
\hline & & & & & & & & & & & $(0.25)$ & & & & $(-0.59)$ & & $(0.24)$ & $(-0.10)$ & $(0.29)$ \\
\hline \multirow[t]{2}{*}{ conf } & & & & & & & & & & & & -0.024 & & & -0.015 & & & -0.037 & -0.083 \\
\hline & & & & & & & & & & & & $(-0.12)$ & & & $(-0.08)$ & & & $(-0.21)$ & $(-0.44)$ \\
\hline \multirow[t]{2}{*}{ ideol } & & & & & & & & & & & & & $0.347^{* *}$ & & & & & & 0.091 \\
\hline & & & & & & & & & & & & & $(2.10)$ & & & & & & $(0.42)$ \\
\hline \multirow[t]{2}{*}{ relig } & & & & & & & & & & & & & & -0.359 & & & & & 0.799 \\
\hline & & & & & & & & & & & & & & $(-0.64)$ & & & & & $(0.80)$ \\
\hline Obs & 74 & 74 & 74 & 74 & 74 & 74 & 47 & 68 & 74 & 74 & 67 & 55 & 72 & 74 & 55 & 74 & 67 & 55 & 53 \\
\hline$R^{2}$ & 0.554 & 0.641 & 0.555 & 0.568 & 0.662 & 0.572 & 0.708 & 0.722 & 0.666 & 0.662 & 0.602 & 0.637 & 0.696 & 0.668 & 0.642 & 0.667 & 0.605 & 0.653 & 0.688 \\
\hline$N$ & 33 & 33 & 33 & 33 & 33 & 33 & 26 & 33 & 33 & 33 & 31 & 26 & 32 & 33 & 26 & 33 & 31 & 26 & 25 \\
\hline$T$ & 2.242 & 2.242 & 2.242 & 2.242 & 2.242 & 2.242 & 1.808 & 2.061 & 2.242 & 2.242 & 2.161 & 2.115 & 2.250 & 2.242 & 2.115 & 2.242 & 2.161 & 2.115 & 2.120 \\
\hline
\end{tabular}

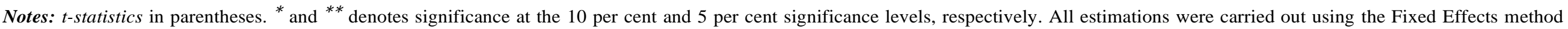

allowing for both country and decade specific effects with cluster-robust standard errors. 
Table 6. Culture and Labour Productivity (Alternative Dimensions of Culture) - Including Additional Control Variables

\begin{tabular}{|c|c|c|c|c|c|c|c|}
\hline & (1) & $(2)$ & (3) & (4) & $(5)$ & (6) & $(7)$ \\
\hline culture & $\begin{array}{l}0.880^{* *} \\
(3.21)\end{array}$ & & & & & & \\
\hline trust & & $\begin{array}{l}-0.147 \\
(-0.60)\end{array}$ & & & & & \\
\hline control & & & $\begin{array}{c}1.629 * * \\
(3.31)\end{array}$ & & & & \\
\hline work & & & & $\begin{array}{c}0.834 * * \\
(2.17)\end{array}$ & & & \\
\hline obedience & & & & & $\begin{array}{c}-0.727 * * \\
(-2.31)\end{array}$ & & \\
\hline competition & & & & & & $\begin{array}{l}0.144 \\
(0.59)\end{array}$ & \\
\hline honesty & & & & & & & $\begin{array}{l}0.058 \\
(0.21)\end{array}$ \\
\hline$g d p$ & $\begin{array}{l}-1.937 * * \\
(-2.40)\end{array}$ & $\begin{array}{l}-2.923 * * \\
(-3.08)\end{array}$ & $\begin{array}{l}-3.236 * * \\
(-4.10)\end{array}$ & $\begin{array}{l}-2.082 * * \\
(-2.08)\end{array}$ & $\begin{array}{l}-2.062 * * \\
(-4.06)\end{array}$ & $\begin{array}{l}-4.229 * * \\
(-2.43)\end{array}$ & $\begin{array}{l}-2.820 * * \\
(-3.10)\end{array}$ \\
\hline open & $\begin{array}{l}3.577 * * \\
(3.10)\end{array}$ & $\begin{array}{l}2.896 * * \\
(2.57)\end{array}$ & $\begin{array}{l}3.479 * * \\
(3.97)\end{array}$ & $\begin{array}{l}3.251^{* *} \\
(3.06)\end{array}$ & $\begin{array}{l}3.453 * * \\
(3.16)\end{array}$ & $\begin{array}{l}1.971 \\
(0.96)\end{array}$ & $\begin{array}{l}3.031 \text { ** } \\
(2.65)\end{array}$ \\
\hline hcap & $\begin{array}{l}-1.243^{*} \\
(-1.91)\end{array}$ & $\begin{array}{l}-1.722 * * \\
(-3.32)\end{array}$ & $\begin{array}{l}-1.348 * * \\
(-2.04)\end{array}$ & $\begin{array}{l}-1.287 * * \\
(-2.23)\end{array}$ & $\begin{array}{l}-1.385 * * \\
(-2.55)\end{array}$ & $\begin{array}{l}-1.053 \\
(-0.58)\end{array}$ & $\begin{array}{l}-1.664 * * \\
(-2.71)\end{array}$ \\
\hline Obs & 74 & 76 & 74 & 76 & 76 & 59 & 76 \\
\hline$R^{2}$ & 0.662 & 0.580 & 0.674 & 0.614 & 0.630 & 0.534 & 0.578 \\
\hline$N$ & 33 & 34 & 33 & 34 & 34 & 34 & 34 \\
\hline$T$ & 2.242 & 2.235 & 2.242 & 2.235 & 2.235 & 1.735 & 2.235 \\
\hline
\end{tabular}

Notes: $t$-statistics in parentheses. ${ }^{*}$ and ${ }^{* *}$ denotes significance at the 10 per cent and 5 per cent significance levels, respectively. All estimations were carried out using the Fixed Effects method allowing for both country and decade specific effects with cluster-robust standard errors. 
Table 7. Culture and Labour Productivity (Alternative Country Samples)

\begin{tabular}{llllll}
\hline & $(1)$ & $(2)$ & $(3)$ & $(4)$ & $(5)$ \\
& Full & OECD24 & Europe & EU & EA12 \\
\hline culture & $0.880^{* *}$ & $0.887^{* *}$ & $1.000^{* *}$ & $1.224^{* *}$ & $1.053^{* *}$ \\
& $(3.21)$ & $(3.00)$ & $(3.09)$ & $(3.57)$ & $(2.26)$ \\
gdp & $-1.937^{* *}$ & -1.881 & -1.758 & 1.653 & 1.148 \\
& $(-2.40)$ & $(-1.14)$ & $(-0.87)$ & $(1.45)$ & $(0.72)$ \\
open & $3.577 * *$ & $3.650^{* *}$ & $3.742^{* *}$ & 0.244 & 0.457 \\
& $(3.10)$ & $(3.16)$ & $(2.14)$ & $(0.15)$ & $(0.25)$ \\
hcap & $-1.243^{*}$ & $-1.277 *$ & -1.111 & -0.097 & -0.596 \\
& $(-1.91)$ & $(-1.78)$ & $(-1.23)$ & $(-0.14)$ & $(-0.64)$ \\
\hline Obs & 74 & 62 & 54 & 44 & 31 \\
$R^{2}$ & 0.662 & 0.620 & 0.652 & 0.839 & 0.860 \\
$N$ & 33 & 24 & 25 & 21 & 12 \\
$T$ & 2.242 & 2.583 & 2.160 & 2.095 & 2.583 \\
\hline
\end{tabular}

Notes: $t$-statistics in parentheses. ${ }^{*}$ and ${ }^{* *}$ denotes significance at the 10 per cent and 5 per cent significance levels, respectively. All estimations were carried out using the Fixed Effects method allowing for both country and decade specific effects with cluster-robust standard errors. 
Table 8. Culture and Labour Productivity (Alternative Dimensions of Culture)

- Including Additional Control Variables and Using Standardized Measures

\begin{tabular}{|c|c|c|c|c|c|c|c|}
\hline & (1) & (2) & (3) & (4) & (5) & (6) & (7) \\
\hline culture & $\begin{array}{l}1.165 * * \\
(3.21)\end{array}$ & & & & & & \\
\hline trust & & $\begin{array}{l}-0.210 \\
(-0.60)\end{array}$ & & & & & \\
\hline control & & & $\begin{array}{l}1.132 * * \\
(3.31)\end{array}$ & & & & \\
\hline work & & & & $\begin{array}{l}0.763 * * \\
(2.17)\end{array}$ & & & \\
\hline obedience & & & & & $\begin{array}{l}-0.868 * * \\
(-2.31)\end{array}$ & & \\
\hline competition & & & & & & $\begin{array}{l}0.133 \\
(0.59)\end{array}$ & \\
\hline honesty & & & & & & & $\begin{array}{l}0.068 \\
(0.21)\end{array}$ \\
\hline$g d p$ & $\begin{array}{l}-1.937 * * \\
(-2.40)\end{array}$ & $\begin{array}{l}-2.923 * * \\
(-3.08)\end{array}$ & $\begin{array}{l}-3.236 * * \\
(-4.10)\end{array}$ & $\begin{array}{l}-2.082 * * \\
(-2.08)\end{array}$ & $\begin{array}{l}-2.062 * * \\
(-4.06)\end{array}$ & $\begin{array}{l}-4.229 * * \\
(-2.43)\end{array}$ & $\begin{array}{l}-2.820 * * \\
(-3.10)\end{array}$ \\
\hline open & $\begin{array}{l}3.577 * * \\
(3.10)\end{array}$ & $\begin{array}{l}2.896^{* *} \\
(2.57)\end{array}$ & $\begin{array}{l}3.479 * * \\
(3.97)\end{array}$ & $\begin{array}{l}3.251 * * \\
(3.06)\end{array}$ & $\begin{array}{l}3.453 * * \\
(3.16)\end{array}$ & $\begin{array}{l}1.971 \\
(0.96)\end{array}$ & $\begin{array}{l}3.031 * * \\
(2.65)\end{array}$ \\
\hline hcap & $\begin{array}{l}-1.243 * \\
(-1.91)\end{array}$ & $\begin{array}{l}-1.722 * * \\
(-3.32)\end{array}$ & $\begin{array}{l}-1.348 * * \\
(-2.04)\end{array}$ & $\begin{array}{l}-1.287^{* *} \\
(-2.23)\end{array}$ & $\begin{array}{l}-1.385^{* *} \\
(-2.55)\end{array}$ & $\begin{array}{l}-1.053 \\
(-0.58)\end{array}$ & $\begin{array}{l}-1.664 * * \\
(-2.71)\end{array}$ \\
\hline$\overline{O b s}$ & 74 & 76 & 74 & 76 & 76 & 59 & 76 \\
\hline$R^{2}$ & 0.662 & 0.580 & 0.674 & 0.614 & 0.630 & 0.534 & 0.578 \\
\hline$N$ & 33 & 34 & 33 & 34 & 34 & 34 & 34 \\
\hline$T$ & 2.242 & 2.235 & 2.242 & 2.235 & 2.235 & 1.735 & 2.235 \\
\hline
\end{tabular}

Notes: $t$-statistics in parentheses. ${ }^{*}$ and ${ }^{* *}$ denotes significance at the 10 per cent and 5 per cent significance levels, respectively. All estimations were carried out using the Fixed Effects method allowing for both country and decade specific effects with cluster-robust standard errors. 
Table 9. Culture and Labour Productivity (Robustness over

Alternative Specifications)

\begin{tabular}{llllllll}
\hline & $(1)$ & $(2)$ & $(3)$ & $(4)$ & $(5)$ & $(6)$ & $(7)$ \\
& $\mathrm{FE}$ & $\mathrm{FE}$ & $\mathrm{DFE}$ & $\mathrm{BCFE}$ & $\mathrm{FE}$ & $\mathrm{DFE}$ & $\mathrm{BCFE}$ \\
\hline \multirow{2}{*}{ culture } & $0.356^{* *}$ & $0.802^{* *}$ & $1.184^{* *}$ & $1.294^{* *}$ & $0.880^{* *}$ & $1.162^{* *}$ & $1.239^{* *}$ \\
& $(2.82)$ & $(2.18)$ & $(3.23)$ & $(2.62)$ & $(3.21)$ & $(2.70)$ & $(2.32)$ \\
& $-3.414^{* *}$ & $-2.015^{* *}$ & -1.023 & -1.046 & $-1.937^{* *}$ & -1.113 & -1.155 \\
open & $(-6.74)$ & $(-2.21)$ & $(-0.55)$ & $(-0.57)$ & $(-2.40)$ & $(-0.56)$ & $-0.58)$ \\
& & & & & $3.577^{* *}$ & 0.213 & 1.398 \\
hcap & & & & & $(3.10)$ & $(0.10)$ & $(0.61)$ \\
& & & & & $-1.243^{*}$ & -1.016 & -0.593 \\
lpr $r_{t-1}$ & & & & & $(-1.91)$ & $(-0.62)$ & $(-0.25)$ \\
& & & $-0.320^{* * *}$ & -0.064 & & $-0.337 * *$ & -0.016 \\
\hline Obs & 74 & 74 & 47 & 47 & 74 & 47 & 47 \\
$R^{2}$ & 0.513 & 0.554 & 0.629 & & 0.662 & 0.635 & \\
$N$ & 33 & 33 & 25 & 25 & 33 & 25 & 25 \\
$T$ & 2.242 & 2.242 & 1.880 & 1.880 & 2.242 & 1.880 & 1.880 \\
\hline
\end{tabular}

Notes: $t$-statistics in parentheses. ${ }^{*}$ and ${ }^{* *}$ denotes significance at the 10 per cent and 5 per cent significance levels, respectively. FE is the fixed effects, DFE is the dynamic fixed effects and BCFE is the bias corrected fixed effects estimator respectively. In all estimations (except column 1 where we employ the one-way fixed effects model) we allow for both country and decade specific effects with cluster-robust standard errors. 
Table 10. Culture and Productivity (Robustness using Total Factor Productivity as an Alternative Measure of Productivity)

\begin{tabular}{lllllll}
\hline & $(1)$ & $(2)$ & $(3)$ & $(4)$ & \multicolumn{1}{c}{$(5)$} & \multicolumn{1}{c}{$(6)$} \\
& $\mathrm{FE}$ & $\mathrm{FE}$ & $\mathrm{BCFE}$ & \multicolumn{1}{c}{$\mathrm{FE}$} & \multicolumn{1}{c}{$\mathrm{FE}$} & \multicolumn{1}{c}{$\mathrm{BCFE}$} \\
\hline culture & $0.017^{* *}$ & 0.029 & $0.474^{* *}$ & $0.033^{* *}$ & 0.013 & $0.891^{* *}$ \\
& $(2.13)$ & $(1.13)$ & $(14.64)$ & $(4.22)$ & $(0.65)$ & $(22.80)$ \\
gdp & $0.134^{* *}$ & $0.195^{* *}$ & $-4.148^{* *}$ & $0.230^{* *}$ & $0.181^{* *}$ & $-6.844^{* *}$ \\
& $(2.84)$ & $(3.07)$ & $(-33.18)$ & $(8.46)$ & $(4.31)$ & $(-46.60)$ \\
open & & & & 0.063 & 0.024 & $-0.763^{* *}$ \\
& & & & $(1.04)$ & $(0.33)$ & $(-4.95)$ \\
hcap & & & & $-0.261^{* *}$ & $-0.293^{* *}$ & $5.810^{* *}$ \\
& & & & $(-4.95)$ & $(-4.88)$ & $(35.77)$ \\
$t f p_{t-1}$ & & & & & & $22.147^{* *}$ \\
& & & $(208.86)$ & & & $(448.73)$ \\
\hline Obs & 74 & 74 & 47 & 74 & 74 & 47 \\
$R^{2}$ & 0.455 & 0.469 & & 0.685 & 0.701 & \\
$N$ & 33 & 33 & 25 & 33 & 33 & 25 \\
$T$ & 2.242 & 2.242 & 1.880 & 2.242 & 2.242 & 1.880 \\
\hline
\end{tabular}

Notes: $t$-statistics in parentheses. ${ }^{*}$ and ${ }^{* *}$ denotes significance at the 10 per cent and 5 per cent significance levels, respectively. FE is the fixed effects and BCFE is the bias corrected fixed effects estimator respectively. In all estimations (except columns 1 and 4 where we employ the one-way fixed effects model) we allow for both country and decade specific effects with clusterrobust standard errors. 
Figure 1. Cross-Country Correlation Between Labour Productivity and Culture

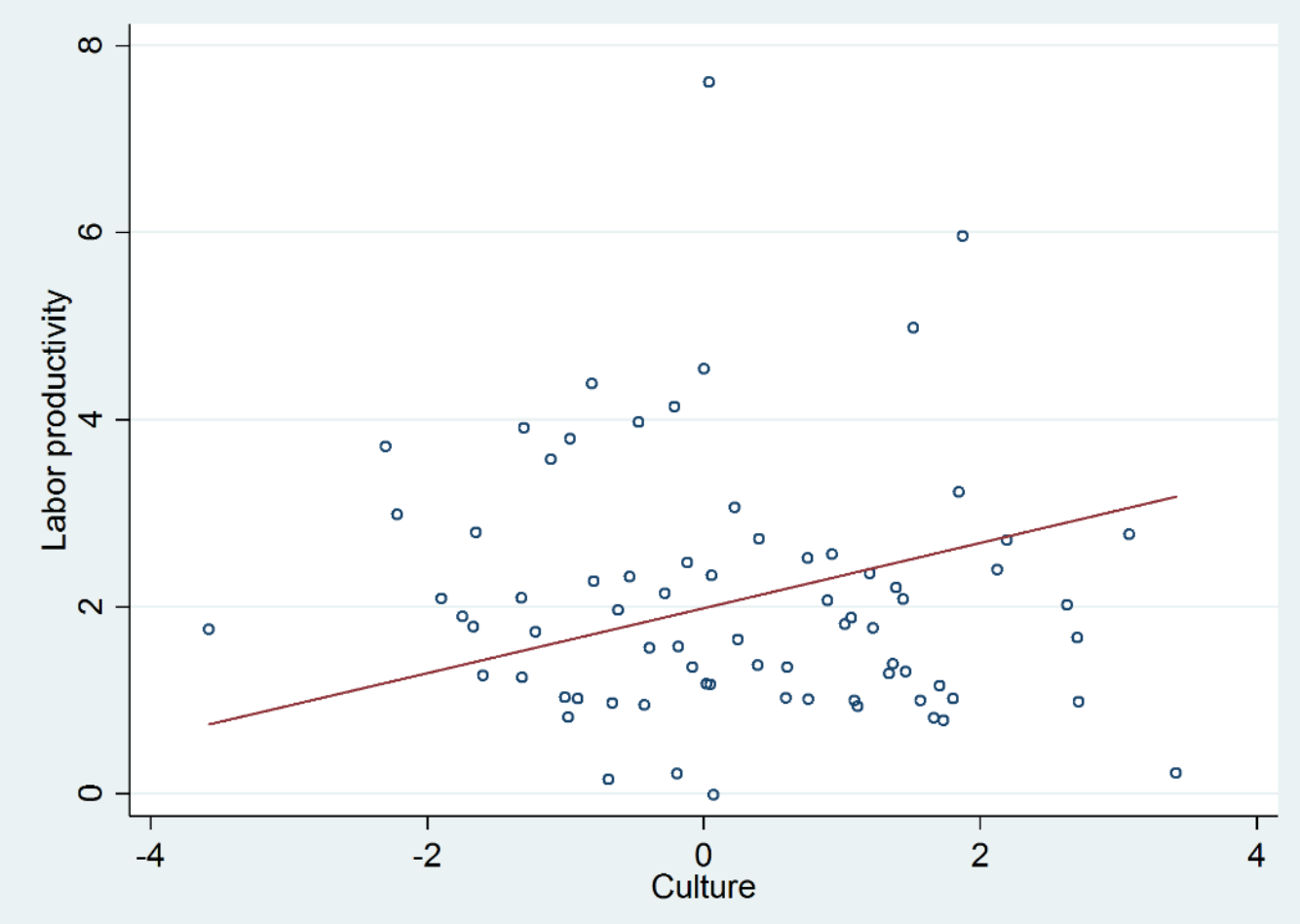

Notes: The graph provides an indication of the positive correlation between culture and labour productivity for the 34 OECD countries over the last three decades (the fitted line is based on the regression model of Equation (1), including the level of GDP per capita as control variable and allowing for country and year fixed effects). 